\title{
Significance of plasma copper and caeruloplasmin concentrations in rheumatoid arthritis
}

\author{
DA VENDRA P. BAJPAYEE \\ From Ethel Lynham Memorial Research Laboratory, Columbus Medical Center Research Foundation, \\ Columbus, Ohio
}

\begin{abstract}
Bajpayee, D. P. (1975). Annals of the Rheumatic Diseases, 34, 162. Significance of plasma copper and caeruloplasmin concentrations in rheumatoid arthritis. To understand the role of copper in initiating protein alterations in rheumatoid arthritis (RA) as reported previously, concentrations of copper and caeruloplasmin were determined in RA patients. The mean copper concentration of the RA population examined was $24.8 \mu \mathrm{mol} / 1$ (157.5 $\mu \mathrm{g} / 100 \mathrm{ml}$ ), and the mean caeruloplasmin concentration in this RA population was $45.52 \mathrm{mg} / 100 \mathrm{ml}$. These values are not different from those reported by previous workers. However, when the RA population was divided into three groups according to sex and oestrogen therapy it was found that caeruloplasmin and copper concentrations in the group of female RA patients on oestrogens was significantly different from other groups $(\mathrm{P}<0.001)$. A highly significant $(\mathrm{P}<0.01)$ positive correlation was obtained between copper and caeruloplasmin concentrations $(r=0.91)$.

Concentrations of copper and caeruloplasmin failed to explain the low sulphydryl content of plasma which was observed to be independent of these two parameters. Increased $\alpha_{2}$-globulin concentration, which was refractory to chrysotherapy but 'finger-printed' with a pure preparation of caeruloplasmin in electrophoresis, along with the absence of Kayser-Fleischer rings, supports the contention that copper is not present in a free ionic state in RA patients. This study shows that only a concurrent oestrogen therapy raises copper and caeruloplasmin concentration significantly in a female RA population. Past investigators appear to have overlooked this fact, and it could be that a disproportionate sex distribution (more female rheumatoid arthritics) could cause misleading results in RA studies. The role of oestrogens, copper, and caeruloplasmin in causing exacerbation of RA symptoms is discussed.
\end{abstract}

This investigation was designed to study plasma copper and caeruloplasmin concentration in rheumatoid arthritis (RA) and to collect data that might prove valuable in understanding the factors causing protein disorders in this disease as mentioned by Lorber, Pearson, Meredith, and Gantz-Mandell (1964). Numerous recent reports have indicated that plasma copper and caeruloplasmin levels are increased in concentration in RA. For instance, Niedermeier and Griggs (1971) have pointed to the fact that mean values of serum copper are significantly higher in the RA population as compared to the normal population. Plantin and Strandberg (1965), using neutron activation analysis, have shown that mean whole blood concentration of copper in RA was considerably raised over that found in a normal population. These studies have reported only overall mean values of copper concentration in RA populations investigated. This has masked the true nature of the data by overlooking the fact that any RA population under study will have a disproportionate sex distribution (female to male 2:1) which could cause misleading interpretation of results. Considering the evidence that caeruloplasmin and copper levels are raised in females taking synthetic oestrogens (Carruthers, Hobbs, and Warren, 1966) and considering the growing contention that oestrogens are implicated in inducing rheumatic symptoms (Kay and Bole, 1971), it was felt that dividing the RA population by sex and oestrogen therapy was essential for rational interpretation of copper and caeruloplasmin concentration data and their relationship to disease activity in RA. The effect of the rise in these two parameters 
on plasma sulphydryl group content has been of further interest and was undertaken to resolve some questions and extend some observations of previous studies carried out by Lorber and co-workers (Lorber, Cutler, and Chang, 1968; Lorber and others, 1964).

\section{Materials and methods}

COLLECTION OF BLOOD SPECIMENS

Blood was collected into heparinized containers from patients who had a diagnosis of definite or classical RA, and normal healthy volunteers of both sexes. The tubes were centrifuged at 2000 r.p.m. to obtain plasma. Plasma was either analysed fresh or was frozen at $-20^{\circ} \mathrm{C}$ till analysed.

\section{ANALYSIS OF COPPER}

Copper was determined in plasma samples by atomic absorption spectrometry using internal standards. The method followed was that described by Lorber and others (1968) except that the standard solution used in this laboratory is a cocktail containing copper and gold at a concentration of $78.7 \mu \mathrm{mol} / 1(500 \mu \mathrm{g} / 100 \mathrm{ml})$ and 25.4 $\mu \mathrm{mol} / 1(500 \mu \mathrm{g} / 100 \mathrm{ml})$, respectively. This mixed standard enables us to utilize the same plasma sample for both copper and gold determinations (for patients on chrysotherapy) by switching to hollow cathode ray tube of the particular metal to be analysed in the sample. All analyses were carried out on Model Dial-Atom atomic absorption spectrometer (Jarrel Ash Division, Fisher Scientific Co.) at $321 \mu$ wavelength.

\section{SULPHYDRYL GROUP ANALYSIS}

Sulphydryl groups were determined in plasma samples by the spectrophotometric method of Ellman (1958). The plasma samples of twenty healthy, normal individuals of both sexes analysed for sulphydryl groups by this method gave a range of $448-734 \mu \mathrm{mol} / 1$ with a mean value of 591 $\mu \mathrm{mol} / 1$.

\section{DETERMINATION OF CAERULOPLASMIN}

Caeruloplasmin was determined in plasma samples by the method outlined by Henry and co-workers (Henry, Chiamori, Jacobs, and Segalove, 1960). Plasma samples with high caeruloplasmin concentration were diluted 1:1 with normal saline before enzyme assay.

STATISTICAL ANALYSIS

Correlation coefficient and linear regression analyses were carried out as described by $\mathrm{Li}(1961)$ to obtain values of $r$, and of the estimated regression equations $\bar{Y}_{x}=a+b$ $(x-\bar{x})$. In this equation $a, b$, and $\vec{Y}_{x}$ denote the sample estimates of $\alpha, \beta$, and $\mu$, respectively, of the classical regression equation $\mu_{y, x}=\alpha+\beta(x-\bar{x})$. Analysis of variance was used to test the hypothesis that mean values of caeruloplasmin and copper in the groups (male RA; female RA; female RA on oestrogens; normal males; normal females) are equal.

\section{Results}

Fig. 1 shows the relationship of copper and caeruloplasmin concentration on 44 RA patients. The mean values for copper and caeruloplasmin of these RA patients were $24.8 \mu \mathrm{mol} / 1(157.5 \mu \mathrm{g} / 100 \mathrm{ml})$ and 45.52 $\mathrm{mg} / 100 \mathrm{ml}$, respectively. A highly significant correlation was observed between copper and caeruloplasmin concentration $(r=0.91 ; P<0.01)$. The mean copper values in this survey are not different from those reported by Lorber and others (1968) and Plantin and Strandberg (1965). The significant correlation of copper and caeruloplasmin found in this study is supported by findings of Antonopoulou, Maragos, Besos, Trichopoulos, Sfikakis, and Daikos (1971). The Table gives mean values of copper and caeruloplasmin in RA patients grouped by sex and oestrogen intake. Analysis of variance shows that the

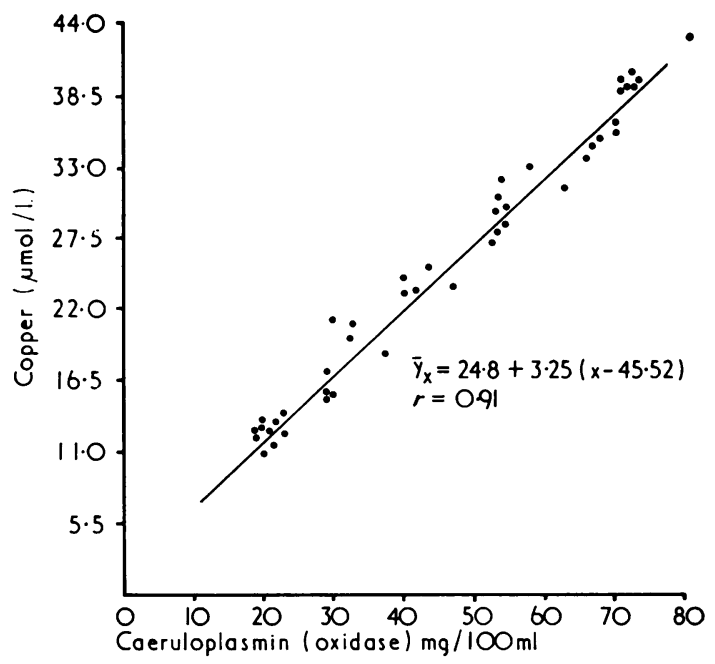

FIG. 1 Scattergram showing plasma copper levels plotted against caeruloplasmin levels

Table Mean copper and caeruloplasmin values in normals and in $R A$ patients grouped according to sex and oestrogen intake

\begin{tabular}{|c|c|c|c|}
\hline & No. patients & Caeruloplasmin $(\mathrm{mg} / 100 \mathrm{ml})$ & Copper ( $\mu \mathrm{mol} / \mathrm{l})$ \\
\hline $\begin{array}{l}\text { Male RA patients } \\
\text { Female RA patients } \\
\text { Female RA patients on oestrogens } \\
\text { Normal males } \\
\text { Normal females }\end{array}$ & $\begin{array}{r}14 \\
14 \\
19 \\
9 \\
13\end{array}$ & $\begin{array}{l}26 \cdot 28(20-34)^{*} \\
31 \cdot 28(20-44) \\
59 \cdot 37(43-74) \dagger \\
27 \cdot 4(18-52) \\
30 \cdot 53(20-47)\end{array}$ & $\begin{array}{l}15 \cdot 4(12 \cdot 4-19 \cdot 7)^{*} \\
17 \cdot 3(11 \cdot 8-23 \cdot 6) \\
32.6(29 \cdot 3-43) \dagger \\
15 \cdot 9(11 \cdot 8-27 \cdot 5) \\
17 \cdot 3(11 \cdot 8-23 \cdot 6)\end{array}$ \\
\hline
\end{tabular}

* Data in parentheses refer to range.

$\uparrow$ Highly significantly $(P<0.001)$ different from other groups. 

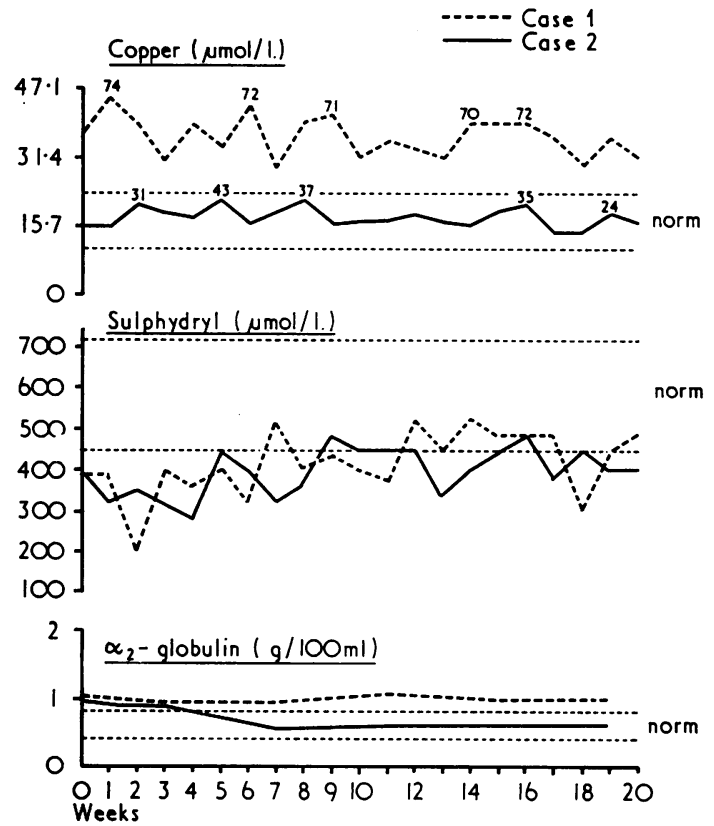

FIG. 2 Typical levels of copper, sulphydryl, and $\alpha_{2}$-globulin in a female patient (Case 1) on oral contraceptive containing synthetic oestrogen and a female patient on no oestrogens (Case 2). The numbers above the copper peaks show the caeruloplasmin concentration of the sample

group of female RA patients on oestrogens has significantly higher levels $(\mathrm{P}<0.001)$ of plasma copper and caeruloplasmin concentration. These data support the previous findings of Niedermeier (1965) that caeruloplasmin accounts for essentially the total increase in copper in RA serum. Fig. 2 compares serial studies on two female patients undergoing chrysotherapy, and shows clearly that the patient on oral contraceptive consistently maintained a high copper and caeruloplasmin level with raised $\alpha_{2}$-globulin. However, the copper and caeruloplasmin content remained normal and the $\alpha_{2}$-globulin dropped under the influence of chrysotherapy in the patient not taking any oestrogens. The $\alpha_{2}$-globulin present in the patient taking oral contraceptive migrated and 'fingerprinted' exactly with a pure commercial caeruloplasmin preparation (Sigma Chemical Co., St. Louis, Mo.) on electrophoresis. These findings are similar to those reported by Bearn and Kunkel (1954), Gubler, Lahey, Brown, Smith, Cartwright, and Wintrobe (1951), and Scheinberg and Morell (1957).

\section{Discussion}

Numerous reports have established the role of both endogenous and exogenous oestrogens in raising the concentration of serum copper and caeruloplasmin (O'Leary and Spellacy, 1969; O'Leary, 1969; O'Leary and Feldman, 1968; Carruthers and others, 1966) in normal females. Oestrogens also produce hypergammaglobulinaemia, increase the number of plasma cells, and produce stromal hypertrophy of spleen in NZB/NZW mice (Walker and Bole, 1971). Oral contraceptives have been shown to initiate antinuclear antibody production, raise the rheumatoid factor titre, and produce a positive LE cell test (Kay and Bole, 1971). Past evidence (Nicol, Vernon-Roberts, and Quantock, 1966a, b; Nicol, Bilbey, Charles, Cordingley, and Vernon-Roberts, 1964) suggests that oestrogens are also highly potent in stimulating the reticuloendothelial system (RES) and in raising body defense. These serological abnormalities induced by oestrogens in RA patients cannot explain the raised levels of copper and caeruloplasmin which are also found in normal

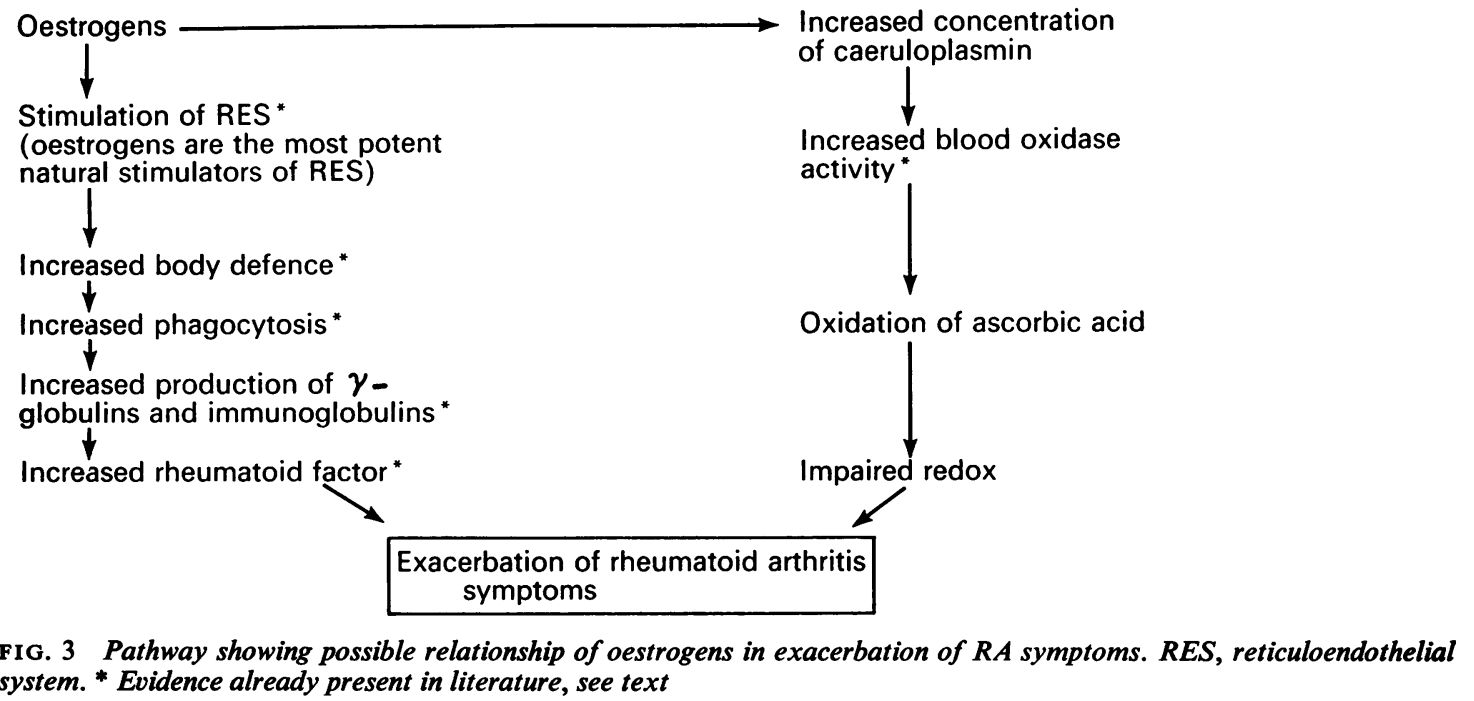


human females taking oral contraceptives. The lack of correlation found between copper and sulphydryl levels in Fig. 2 support the contention that increased caeruloplasmin contributes essentially to the total increase in copper concentration. This copper is not available in the free state to catalyse the oxidation of sulphydryl linkage of proteins (Saroff and Choate, 1958). Additional support that copper is not present in a free state comes from the absence of KayserFleischer rings in RA patients with high copper levels. In contrast, in Wilson's disease KayserFleischer rings are present in $92 \%$ of the cases and the presence of free copper is well established (Cumings, 1971).

Our study fails to confirm the report of Lorber and others (1968) that an error is involved in copper metabolism in RA. However, it shows the specificity of oestrogens in raising caeruloplasmin levels in female RA patients. Fig. 3 presents a scheme through which oestrogens may exacerbate but not produce the symptoms of RA on the basis of evidence cited and the findings of this study. This study shows that copper and sulphydryl estimations are not meaningful parameters to explain the protein disorders found in RA.

I wish to thank Mr. Richard J. McKee for technical assistance, Miss Deborah White for typing the manuscript, and David Yoerger for illustrations and photographs. Thanks are due to the Central Ohio chapter of the Arthritis Foundation for part support of the author.

\section{References}

antonopoulou, M., Maragos, M., Besos, E. I., Trichopoulos, D., Sfikakis, P., and Daikos, G. (1971) in '7th European Rheumatology Congress', Abst. 3.4 'Serum copper and ceruloplasmin levels in rheumatoid arthritis and their relationship to clinical picture of the disease'. European League Against Rheumatism, London

Bearn, A. G., AND Kunkel, H. G. (1954) Proc. Soc. exp. Biol. (N. Y.), 85, 44 (Localization of $\mathrm{Cu}^{64}$ in serum fractions following oral administration. An alteration in Wilson's disease)

Carruthers, M. E., Hobbs, C. B., AND Warren, R. L. (1966) J. clin. Path., 19, 498 (Raised serum copper and caerulpolasmin levels in subjects taking oral contraceptives)

Cumings, J. N. (1971) Proc. roy. Soc. Med., 64, 313 (Inborn errors of metabolism in neurology (Wilson's disease, Refsum's disease and lipidoses))

Ellman, G. L. (1958) Arch. Biochem., 74, 443 (A colorimetric method for determining low concentration of mercaptans)

Gubler, C. J., Lahey, M. E., Brown, D. M., Smith, E. L., Cartwright, G. E., and Wintrobe, M. M. (1951) Fed. Proc., 10, 356 (The form of binding of copper in serum)

Henry, R. J., Chiamori, N., Jacobs, S. L., ANd Segalove, M. (1960) Proc. Soc. exp. Biol. (N. Y.), 104, 620 (Determination of ceruloplasmin oxidase in serum).

KAY, D. R., AND Bole, G. G. (1971) in '7th European Rheumatology Congress', Abst. 7.5 'Oral contraceptives (OC) effects upon rheumatic symptoms and serologic tests'. European League Against Rheumatism, London

LI, J. C. R. (1961) in 'Introduction to Statistical Inference', p. 250. Edward Brothers, Ann Arbor, Michigan

Lorber, A., Cutler, L. S., AND Chang, C. C. (1968) Arthr. and Rheum., 11, 65 (Serum copper levels in rheumatoid arthritis: relationship of elevated copper to protein alterations)

—, Pearson, C. M., Meredith, W. L., and Gantz-Mandell, L. E. (1964) Ann. intern. Med., 61, 423 (Serum sulfhydryl determinations and significance in connective tissue diseases)

Nicol, T., Bilbey, D. L. J., Charles, L. M., Cordingley, J. L., ANd Vernon-Roberts, B. (1964) J. Endocr., 30, 277 (Oestrogen: the natural stimulant of body defense)

- VERnON-Roberts, B., AND QuANTOCK, D. C. (1966a) Ibid., 34, 163 (The effects of oestrogen: androgen interaction on the reticulo-endothelial system and reproductive tract)

$-, \ldots,-(1966 \mathrm{~b})$ Ibid., 35, 119 (Oestrogenic and anti-oestrogenic effects of oestriol, 16-epioestriol, 2 methoxyoestrone and 2,-hydroxy oestradiol-17 $\beta$ on the reticulo-endothelial system and reproductive tract)

Niedermeier, W. (1965) Ann. rheum. Dis., 24, 544 (Concentration and chemical state of copper in synovial fluid and blood serum of patients with rheumatoid arthritis)

—, AND GRIGGS, J. H. (1971) J. chron. Dis., 23, 527 (Trace metal composition of synovial fluid and blood serum of patients with rheumatoid arthritis)

O'Leary, J. A. (1969) Amer. J. Obstet. Gynec., 105, 636 (Serum copper levels as a measure of placental function)

$\longrightarrow$, AND Feldman, M. A. S. (1968) J. Reprod. Med., 2, 185 (Serum copper levels in normal subjects receiving an oral contraceptive)

—, AND Spellacy, W. N. (1969) Amer. J. Obstet. Gynec. 103, 131 (Zinc and copper levels in pregnant women and those taking oral contraceptives)

Plantin, L. O., AND Strandberg, P. O. (1965) Acta rheum. scand., 11, 30 (Whole blood concentrations of copper and zinc in rheumatoid arthritis studied by activation analysis)

SARoff, H. A., AND ChOATE, W. L. (1958) Arch. Biochem., 74, 245 (Reversible aggregation of serum albumin in the reaction with copper (12))

Scheinberg, I. H., AND Morell, A. G. (1957) J. clin. Invest., 36, 1193 (Exchange of ceruloplasmin copper with ionic $\mathrm{Cu}^{64}$ with reference to Wilson's disease)

WAlKer, S. E., AND Bole, G. G. (1971) in '7th European Rheumatology Congress', Abst. 37.1 'Patterns of response to 17- $\beta$-estradiol in an animal model of autiommune disease'. European League Against Rheumatism, London 